\title{
Availability and use of woody plants in a agrarian reform settlement in the cerrado of the state of Goiás, Brazil
}

\author{
Vanessa Pessanha Tunholi ${ }^{1,4}$, Marcelo Alves Ramos² and Aldicir Scariot ${ }^{3}$
}

Received: 5 June, 2012. Accepted: 23 July, 2013

\begin{abstract}
Protected areas are important sources providing plant resources for human populations, and contributing to the livelihood and income of families. To test the ecological apparency hypothesis, that there is positive relationship between the visibility of a species and its use, we conducted an ethnobotanical survey in the protected area of the Itaúna rural settlement in the municipality of Planaltina, in the state of Goiás, in central Brazil. The phytosociological parameters were obtained in 5.6 ha area of the Brazilian cerrado (savanna), and the ethnobotanical survey conducted with semi-structured interviews with 75 people. There was a weak positive correlation between the use value and the phytosociological parameters. A principal component analysis showed that seven species (Pterodon pubescens, Hancornia speciosa, Hymenaea stigonocarpa, Eugenia dysenterica, Annona crassiflora, Stryphnodendron adstringens and Solanum lycocarpum) have high use value, despite having low density, dominance and frequency. Nineteen species showed a positive relationship between their use value and their phytosociological parameters. The relationship between vegetation structure and use value differed among species in the protected area, indicating that more attention should be paid to those under more pressure, with low abundance. Further studies of these seven species should be conducted to determine whether human pressure is affecting populations structures and to define management strategies.
\end{abstract}

Key words: cerrado, ecological apparency, use value, ethnobotany, phytosociology

\section{Introduction}

The main objective of ethnobotany is to understand the interaction between human populations and vegetation. Central to that understanding are the social and ecological contexts that influence the value of plants for people (Lawrence et al. 2005). Accordingly, floristic and ecological data are quite important because they can contribute to a better understanding of the dynamics of the relationship between people and plant resources (Albuquerque et al. 2005).

Phillips \& Gentry (1993a; 1993b) pioneered the research that describes the importance of plant species used by human populations, as measured by the use value (UV) of the species along with their density, dominance and frequency in an area of the Peruvian Amazon, based on the hypothesis of ecological apparency. This hypothesis, proposed by Feeny (1976) for studies of herbivory, suggests that the susceptibility of a plant to consumption by predators is also influenced by its abundance in the community (its ecological apparency). To refer to abundant plants, the author used the term "apparent" meaning visible, or evident. Therefore, a species with high dominance and availability in the vegetation tends to have a higher UV, which is a measure of its relative importance (Lucena 2009). In ethnobotany, corroborate or refute this hypothesis can contribute to the theoretical debate over the possible influence of environmental factors on cultures (Phillips \& Gentry 1993b). The ecological apparency hypothesis in the ethnobotanical context has been tested in search of variables able to predict the UV of species (e.g., Phillips \& Gentry 1993b; Lawrence et al. 2005; Galeano 2000; Ferraz et al. 2006; Lucena 2009; La Torre-Cuadros \& Islebe 2003).

Understanding the variables that are related to the use of tree species can contribute to the maintenance of the vegetation in biomes which are quickly being converted to other uses. One example is the Brazilian Cerrado, the richest savanna in the world in terms of the number of species and the second largest Brazilian biome. The cerrado

\footnotetext{
${ }^{1}$ Universidade de Brasília, Programa de Pós-Graduação em Ecologia, Brasília, DF, Brazil

${ }^{2}$ Universidade de Pernambuco, Campus Mata Norte, Departamento de Ciências Biológicas, Nazaré da Mata, PE, Brazil

${ }^{3}$ Embrapa Recursos Genéticos e Biotecnologia, Brasília, DF, Brazil

${ }^{4}$ Author for correspondence: vanessa.tunholi@gmail.com
} 
is a global biodiversity hotspot with high endemism and a high rate of deforestation (Myers et al. 2000). It also harbors the sources of the rivers that feed the São Francisco, Amazonas and Paraná basins, the three main basins of Brazil, and is home to 12,070 species of plants with high levels of endemism (34.9\%) (Forzza et al. 2010). Native vegetation has been removed to accommodate grain farming and livestock raising, mainly export-oriented, to the point that $48.5 \%$ of the vegetation had been destroyed by 2008 (www. mma.gov.br/portalbio, accessed on August 31,2010), and it is unknown how much of the remaining area is degraded due to unsustainable use (Scariot 2010).

In the last two decades a significant number of agrarian settlements for landless farmers has been founded in the Brazilian Cerrado. By the end of 2009, the state of Goiás and the Federal District collectively had 442 agrarian reform settlement projects, occupying a total area of $11,289.54 \mathrm{~km}^{2}$ (www.incra.gov.br, accessed January 20, 2011). However, there is a lack of information regarding the knowledge and use that farmers make of the biodiversity of the protected areas existing nearby at settlements, which is of particular importance, as these farmers hail from several different regions of Brazil with varying experiences and knowledge of the use of plants.

Studies relating the ecological apparency hypothesis have yet to be carried out in the agrarian reform settlements of the cerrado. Such studies could contribute to a better understanding of the settlers' relationship with the plant species of the protected area and, consequently, of their role in the conservation of the remaining vegetation. As knowledge of these relationships may play a key role in the maintenance and management of biodiversity and the planning of settlements in the region, the aim of the present study was to test the ecological apparency hypothesis.

\section{Materials and methods}

\section{Study area}

The study was conducted in the Itaúna Settlement Project, located in the São Gabriel district of the municipality of Planaltina, in the state of Goiás (North: $15^{\circ} 09^{\prime} 02^{\prime \prime}$; $47^{\circ} 39^{\prime} 56^{\prime \prime}$ W-South: $15^{\circ} 15^{\prime} 34^{\prime \prime}$; $47^{\circ} 38^{\prime} 34^{\prime \prime}$ W-West: $15^{\circ} 11^{\prime} 44^{\prime \prime} S$; $47^{\circ} 39^{\prime} 43^{\prime \prime} \mathrm{W}$-East: $15^{\circ} 11^{\prime} 18^{\prime \prime} S$; $47^{\circ} 35^{\prime} 27^{\prime \prime} \mathrm{W}$ ), with a total area of 4126.8 ha (INCRA 2008). According to the Köppen system of classification, the climate is type Cwa, with a rainy season (October through April) and a dry season (May through September). The average annual rainfall is $1500 \mathrm{~mm}$. According to data provided by the Brazilian National Institute of Meterology, originating from the Águas Emendadas weather station in the Federal District, total rainfall amounts for 2009 and 2010 were $1707 \mathrm{~mm}$ and $1429 \mathrm{~mm}$, respectively. The elevation in the settlement varies from $975 \mathrm{~m}$ to $1251 \mathrm{~m}$. The settlement also contains a protected area with vegetation typical of cerrado sensu stricto, which occupies $25.6 \%$ of the area of the settlement and is in a reasonable state of conservation.

The settlement consists of 100 families, originating from all the five regions of Brazil. The first families arrived in the area in 1997, when the settlement was established, but the settlementwas officially founded only in 2007 (INCRA Ordinance SR-28 No. 35). Agriculture is the main activity practiced by the settlers, and there are very few collective works in the settlement-as has been observed in several settlements in the area surrounding the Federal District of Brasília.

Data survey - To test the ecological apparency hypothesis, we used phytosociological data (Tab. 1) obtained through a forest inventory carried out in 56 randomly allocated plots, each measuring $20 \times 50 \mathrm{~m}$ (total sample area of $5.6 \mathrm{ha}$ ) in the communal protected area, We sampled all tree individuals with a diameter $\geq 5 \mathrm{~cm}$ at $30 \mathrm{~cm}$ above the ground, and estimated density, dominance and frequency to test the ecological apparency hypothesis.

To obtain information on the uses of woody plants that occur in the protected area and on the social profile of the informants, between April and August of 2010 we conducted semi-structured interviews with the settlers, with free listing of the useful species of the reserve. In the interviews, we also collected socio-cultural data, such as level of education, length of residence in the settlement, city of birth, age and sex. Altogether, 75 people from 73 families were interviewed. Although we visited all 100 homes in the settlement, some residents were not present at the time of the visit (27 homes). The plants mentioned in the interviews were collected with the aid of three key informants and deposited in the Herbarium of Embrapa Genetic Resources and Biotechnology (code, CEN), a unit of the the Brazilian Agricultural Research Corporation (Embrapa), located in the city of Brasília. Specimens were identified by specialists, by technicians and through comparisons with herbarium vouchers. Upon completion of the interviews, we used herbarium specimens and photographs as visual stimuli with informants who cited species that presented with homonyms (the same common name to denote different plant species): Byrsonima verbascifolia, Byrsonima crassifolia, Byrsonima coccolobifolia, Pterodon pubescens, Bowdichia virgilioides, Machaerium opacum, Dalbergia miscolobium, Psidium laruotteanum and Psidium myrsinoides. Although the use of stimuli, such as herbarium specimens and photographs, can sometimes make it difficult for the informants to identify the species (Medeiros et al., 2008), they were important in the present study as it enabled analyses to be performed at the species level, rather than just at the level of genus or ethnospecies.

Data analysis - The plants mentioned in the interviews were grouped into five categories of use commonly adopted in ethnobotanical studies: food, firewood, construction, medicinal and veterinary. The UV was calculated for each 
Table 1. Phytosociological and ethnobotanical parameters for useful tree species in the protected area located near of the Itaúna Settlement Project in the municipality of Planaltina, state of Goiás, Brazil.

\begin{tabular}{|c|c|c|c|c|c|c|c|}
\hline $\begin{array}{l}\text { Family } \\
\text { Species }\end{array}$ & Common name (Voucher \#) & Use(s) & UV & $\mathrm{n}$ & $\mathrm{RD}$ & $\mathrm{RF}$ & RDo \\
\hline \multicolumn{8}{|l|}{ Annonaceae } \\
\hline Annona crassiflora Mart. & Araticum/articum (VPT \#56) & Fo & 0.8 & 52 & 0.38 & 0.75 & 0.31 \\
\hline \multicolumn{8}{|l|}{ Apocynaceae } \\
\hline Aspidosperma subincanum Mart. ex A. DC. & Pereira (VPT \#57) & $\mathrm{C}, \mathrm{M}$ & 0.0 & 3 & 0.00 & 0.00 & 0.00 \\
\hline Hancornia speciosa Gomes & Mangaba (VPT \#41) & Fo, Fi, M & 1.2 & 61 & 1.32 & 2.36 & 0.70 \\
\hline Himatanthus obovatus (Müll. Arg.) Woodson & Pau de leite/tiborna (VPT \#59) & M & 0.0 & 1 & 0.07 & 0.11 & 0.02 \\
\hline \multicolumn{8}{|l|}{ Araliaceae } \\
\hline Schefflera macrocarpa (Cham. \& Schltdl.) Frodin & Mandiocão (VPT \#6) & $\mathrm{V}, \mathrm{Fi}$ & 0.1 & 4 & 1.32 & 2.26 & 1.16 \\
\hline \multicolumn{8}{|l|}{ Bignoniaceae } \\
\hline Zeyheria montana Mart. & Bolsa de pastor (VPT \#43) & M & 0.0 & 1 & 0.00 & 0.00 & 0.00 \\
\hline \multicolumn{8}{|l|}{ Calophyllaceae } \\
\hline Kielmeyera coriacea Mart. \& Zucc. & Pau santo (VPT \#24) & $\mathrm{V}$ & 0.0 & 1 & 5.08 & 3.87 & 3.02 \\
\hline \multicolumn{8}{|l|}{ Caryocaraceae } \\
\hline Caryocar brasiliense St. Hil. & Pequi (VPT \#53) & Fo, $\mathrm{M}$ & 1.0 & 69 & 2.78 & 3.01 & 8.42 \\
\hline \multicolumn{8}{|l|}{ Celastraceae } \\
\hline Salacia crassifolia (Mart. ex Schult.) G. Don & Bacupari/saputá(VPT \#54) & $\mathrm{Fo}, \mathrm{Fi}$ & 0.4 & 28 & 2.33 & 3.01 & 1.78 \\
\hline \multicolumn{8}{|l|}{ Combretaceae } \\
\hline Terminalia argentea Mart. & Capitão (VPT \#29) & M & 0.0 & 1 & 0.00 & 0.00 & 0.00 \\
\hline \multicolumn{8}{|l|}{ Diliniaceae } \\
\hline Davilla elliptica A. St.-Hil. & Sambaibinha (VPT \#7) & $\mathrm{V}, \mathrm{M}$ & 0.1 & 3 & 10.33 & 4.08 & 5.75 \\
\hline \multicolumn{8}{|l|}{ Euphorbiceae } \\
\hline Croton urucurana Baill. & Sangue de Cristo (VPT \#15) & M & 0.0 & 1 & 0.00 & 0.00 & 0.00 \\
\hline \multicolumn{8}{|l|}{ Fabaceae } \\
\hline Acosmium dasycarpum (Vogel) Yakovlev & Unha d'anta (VPT \#11) & $\mathrm{V}, \mathrm{M}$ & 0.1 & 4 & 0.38 & 0.97 & 0.18 \\
\hline Anadenanthera colubrina (Vell.) Brenan & Angico (VPT \#10) & $\mathrm{Fi}, \mathrm{C}, \mathrm{M}$ & 0.1 & 3 & 0.00 & 0.00 & 0.00 \\
\hline Bowdichia virgilioides Kunth & Sucupira preta (VPT \#49) & $\mathrm{V}, \mathrm{Fi}, \mathrm{C}, \mathrm{M}$ & 0.2 & 9 & 0.97 & 2.36 & 1.34 \\
\hline Dalbergia miscolobium Benth. & Cabiúna/jacarandá(VPT \#74) & $\mathrm{Fi}, \mathrm{C}$ & 0.1 & 8 & 1.74 & 2.36 & 2.89 \\
\hline Dimorphandra mollis Benth. & Favela/faveira (VPT \#9) & $\mathrm{V}, \mathrm{Fi}, \mathrm{C}, \mathrm{M}$ & 0.3 & 20 & 1.04 & 1.83 & 0.56 \\
\hline Hymenaea stigonocarpa Mart. ex Hayne & Jatobá (VPT \#60) & Fo, Fi, C, M & 1.0 & 46 & 1.70 & 2.26 & 1.50 \\
\hline Machaerium opacum Vogel & Jacarandá (VPT \#75) & $\mathrm{Fi}, \mathrm{C}$ & 0.0 & 1 & 0.03 & 0.11 & 0.03 \\
\hline Pterodon pubescens (Benth.) Benth. & Sucupira branca (VPT \#76) & $\mathrm{V}, \mathrm{Fi}, \mathrm{C}, \mathrm{M}$ & 1.2 & 57 & 0.49 & 0.75 & 1.72 \\
\hline Plathymenia reticulata Benth. & Vinhático (VPT \#32) & $\mathrm{V}$ & 0.0 & 1 & 0.00 & 0.00 & 0.00 \\
\hline Sclerolobium paniculatum Vogel & Carvoeiro (VPT \#61) & $\mathrm{Fi}, \mathrm{C}$ & 0.9 & 52 & 4.97 & 3.22 & 9.73 \\
\hline Stryphnodendron adstringens (Mart.) Coville & Barbatimão (VPT \#65) & $\mathrm{V}, \mathrm{Fi}, \mathrm{C}, \mathrm{M}$ & 0.7 & 37 & 1.46 & 1.83 & 1.48 \\
\hline \multicolumn{8}{|l|}{ Loganiaceae } \\
\hline Strychnos pseudoquina A. St.-Hil & Quina (VPT \#63) & $\mathrm{V}, \mathrm{Fi}, \mathrm{M}$ & 0.3 & 15 & 0.80 & 1.72 & 0.75 \\
\hline \multicolumn{8}{|l|}{ Lythraceae } \\
\hline Lafoensia pacari A. St.-Hil. & Pacari (VPT \#2) & V, Fi, M & 0.3 & 17 & 0.66 & 0.97 & 0.76 \\
\hline \multicolumn{8}{|l|}{ Malpighiaceae } \\
\hline Byrsonima coccolobifolia Kunth & Murici/muricizão (VPT \#21) & $\mathrm{Fo}, \mathrm{Fi}$ & 0.3 & 13 & 3.44 & 4.08 & 2.34 \\
\hline Byrsonima crassifolia (L.) Kunth & Murici/muricizão (VPT \#13) & $\mathrm{Fo}, \mathrm{Fi}$ & 0.3 & 18 & 0.28 & 0.54 & 0.15 \\
\hline Byrsonima verbascifolia (L.) Rich. ex Juss. & Murici/muricizão (VPT \#77) & $\mathrm{Fo}, \mathrm{Fi}$ & 0.5 & 29 & 2.40 & 2.79 & 1.23 \\
\hline \multicolumn{8}{|l|}{ Moraceae } \\
\hline Maclura tinctoria (L.) D. Don ex Steud. & Moreira (VPT \#78) & M & 0.0 & 1 & 0.00 & 0.00 & 0.00 \\
\hline Brosimum gaudichaudii Trécul & Fruta de cera/mama cadela (VPT \#52) & Fo, $M$ & 0.4 & 22 & 0.00 & 0.00 & 0.00 \\
\hline \multicolumn{8}{|l|}{ Myrtaceae } \\
\hline Eugenia dysenterica DC. & Cagaita (VPT \#79) & Fo, Fi, M & 0.7 & 40 & 0.42 & 0.86 & 0.32 \\
\hline Psidium myrsinoides O. Berg & Araçá/goiabinha (VPT \#14) & $\mathrm{Fo}, \mathrm{Fi}$ & 0.1 & 5 & 1.29 & 1.83 & 0.68 \\
\hline Psidium laruotteanum Cambess. & Araçá/goiabinha (VPT \#51) & Fo, Fi, M & 0.2 & 12 & 0.10 & 0.21 & 0.05 \\
\hline
\end{tabular}


Table 1. Continuation.

\begin{tabular}{|c|c|c|c|c|c|c|c|}
\hline $\begin{array}{l}\text { Family } \\
\text { Species }\end{array}$ & Common name (Voucher \#) & Use(s) & UV & $\mathrm{n}$ & $\mathrm{RD}$ & $\mathrm{RF}$ & RDo \\
\hline \multicolumn{8}{|l|}{ Ochnaceae } \\
\hline Ouratea hexasperma (A. St.-Hil.) Baill. & Cabelo de nego (VPT \#50) & $\mathrm{V}$ & 0.0 & 1 & 5.77 & 3.11 & 3.00 \\
\hline \multicolumn{8}{|l|}{ Opiliaceae } \\
\hline Agonandra brasiliensis Miers ex Benth. \& Hook. f. & Cerveja de pobre (VPT \#62) & $\mathrm{Fi}, \mathrm{M}$ & 0.0 & 1 & 0.14 & 0.43 & 0.05 \\
\hline \multicolumn{8}{|l|}{ Rubiaceae } \\
\hline Alibertia edulis (Rich.) A. Rich. ex DC. & Marmelo (VPT \#80) & Fo & 0.0 & 1 & 0.00 & 0.00 & 0.00 \\
\hline Palicourea rigida Kunth & Chapéu de couro (VPT \#44) & $\mathrm{Fi}, \mathrm{C}, \mathrm{M}$ & 0.2 & 12 & 0.28 & 0.64 & 0.10 \\
\hline Tocoyena formosa (Cham. \& Schltdl.) K. Schum. & Jenipapo de cavalo/Jenipapo bravo (VPT \#39) & $\mathrm{V}$ & 0.0 & 1 & 0.14 & 0.43 & 0.04 \\
\hline \multicolumn{8}{|l|}{ Sapindaceae } \\
\hline Dilodendron bipinnatum Radlk & Maria pobre (VPT \#81) & M & 0.0 & 1 & 0.00 & 0.00 & 0.00 \\
\hline \multicolumn{8}{|l|}{ Sapotaceae } \\
\hline Pouteria ramiflora (Mart.) Radlk. & Grão de galo (VPT \#48) & Fo, Fi & 0.1 & 8 & 3.30 & 3.33 & 4.42 \\
\hline \multicolumn{8}{|l|}{ Solanaceae } \\
\hline Solanum lycocarpum A. St.-Hil. & Lobeira (VPT \#25) & V, Fo, Fi, M & 0.4 & 20 & 0.03 & 0.11 & 0.02 \\
\hline \multicolumn{8}{|l|}{ Styracaceae } \\
\hline Styrax ferrugineus Nees \& Mart. & Laranjinha (VPT \#30) & Fo, Fi, M & 0.1 & 5 & 1.88 & 2.15 & 1.93 \\
\hline \multicolumn{8}{|l|}{ Vochysiaceae } \\
\hline Callisthene fasciculata Mart. & Jacaré (VPT \#82) & $\mathrm{Fi}$ & 0.0 & 1 & 0.00 & 0.00 & 0.00 \\
\hline Callisthene major Mart. & Farinha Seca (VPT \#83) & $\mathrm{Fi}$ & 0.0 & 1 & 0.00 & 0.00 & 0.00 \\
\hline Qualea grandiflora Mart. & Pau terra da folha larga (VPT \#31) & $\mathrm{V}, \mathrm{Fi}, \mathrm{C}, \mathrm{M}$ & 0.3 & 19 & 3.93 & 2.90 & 3.91 \\
\hline Qualea parviflora Mart. & Pau terra da folha pequena (VPT \#18) & V, Fi, M & 0.1 & 6 & 16.07 & 4.94 & 21.77 \\
\hline Vochysia rufa Mart. & Pau doce (VPT \#3) & M & 0.0 & 2 & 0.49 & 1.07 & 0.46 \\
\hline Vochysia thyrsoidea Pohl & Gomeira (VPT \#84) & M & 0.0 & 1 & 0.14 & 0.21 & 0.23 \\
\hline
\end{tabular}

$\mathrm{RD}$ - Relative density (\%); RF - Relative frequency; RDo - Relative dominance (\%); UV - use value; $\mathrm{n}$ - number of respondents who cited each species; $\mathrm{V}$ - veterinary; $\mathrm{M}$ - medicinal; Fi - firewood; Fo - food; C - construction.

Dead specimens presented the following values: $\mathrm{RD}=4.17$; $\mathrm{RF}=4.08$; and $\mathrm{RDo}=5.30$.

species, botanical family and category of use, as well as for each species in each category of use, with the indices proposed by Phillips and Gentry (1993a), as modified by Rossato et al. (1999) and Galeano (2000):

$$
\begin{gathered}
U V s=\Sigma U s . n i^{-1} \\
U V c=\Sigma U V s c \\
U V s c=\Sigma U s c . n i^{-1}
\end{gathered}
$$

where $U V s$ is the use value for each species, $U s$ is the number of uses mentioned for each species, $n i$ is the total number of informants, $U V c$ is the UV of a category, UVsc is the UV of each species in the category, and Usc is the number of uses for each species listed in the category. The UV of each botanical family was calculated by summing the UV values of the species within the family (Galeano 2000). To minimize the limitations of the UV indicated by Stagegaard et al. (2002), who suggested that the increase of the estimates may be related to potential uses never realized, the informants were asked to cite species from the protected area that they actually used and not those of which they merely knew. The differences between use categories were tested by the Kruskal-Wallis test. The herbaceous, shrub, exotic and palm species mentioned were not included in the analyses.

To evaluate the possible correlation between the use of woody plants and their availability in the environment (ecological apparency hypothesis), as expressed by phytosociological parameters, we applied the Spearman correlation test, using BioStat, version 4.0 (Ayres et al. 2005). Species cited as useful but not sampled in the forest inventory were disregarded. The correlation analysis was performed considering the UV of each species and the UV of all species in each use category individually. It was not possible to perform regression analysis due to a lack of data normality. To check the influence of the phytosociological parameters and of the UV on the formation of groups of similar species, we performed a principal component analysis (PCA) with the program R (R Development Core Team, 2008) and the Vegan package (Oksanen et al. 2008). In this analysis we removed species that occurred in the protected area but were not used by the settlers and those used but not sampled in the forest inventory. 


\section{Results}

\section{Use of resources}

The informants cited 48 useful species, distributed in 42 genera and 24 families, and 36 of those species occurred in the forest inventory of the protected area. The remaining 12 species cited were not sampled because they are rare in the area, occurring in gallery forests or are, in general, of low frequency, not reaching the threshold for inclusion used in the forest inventory. Among the species cited, the informants reported that $61.2 \%$ were of medicinal use, $57.1 \%$ were used for firewood, $32.6 \%$ were of food use, $32.6 \%$ were of veterinary use and $22.4 \%$ were used in construction. The category with the highest UV was food use (UV=5.1), which accounted for $40.1 \%$ of the specific uses cited and differed significantly from the other categories $(\mathrm{H}=15.9 ; \mathrm{p}<0.01)$. According to the informants, the part of the plant most often used was the fruit (49.8\%; $\mathrm{H}=20.8 ; \mathrm{p}=0.0009)$, followed by the wood (23\%) and the outer bark/inner bark (15.5\%).

The Fabaceae family had the highest number of species considered useful (11 species) and accounted for the largest proportion of use citations (36.7\%), followed by Apocynaceae $(10.1 \%)$, Malpighiaceae $(8.5 \%)$, Caryocaraceae (7.9\%) and Myrtaceae (7.7\%). The plant resources of the cerrado are mainly used for household consumption, and commercialization occurs only with the fruits of Annona crassiflora and Pterodon pubescens in nearby markets and by only $5.3 \%$ of the informants.

The highest UV values were recorded for Pterodon $p u$ bescens (1.2), Hancornia speciosa (1.2), Hymenaea stigonocarpa (1) and Caryocar brasiliense (1). Twenty-five species presented very low UV values $(<0.1)$, and only 15 species had a UV higher than 0.3 (Tab. 1).

\section{Ecological apparency and use of forest resources}

Among the eight species with an importance value $\geq 10$ (IV, represented by the sum of the relative phytosociological parameters), only Sclerolobium paniculatum, Caryocar brasiliense and Qualea grandiflora had 10 or more citations of use, corresponding to a UV $\geq 0.13$.

The mean UV was found to correlate positively with the individual means for density ( $\mathrm{r}=0.43, \mathrm{p}=0.0001)$, frequency ( $\mathrm{rs}=0.45, \mathrm{p}<0.0001)$, dominance $(\mathrm{rs}=0.46, \mathrm{p}<0.0001)$ and IV ( $\mathrm{rs}=0.47, \mathrm{p}<0.0001)$ of the species. This result indicates a trend for the most abundant species to be the most used, and to have a greater number of uses. However, no significant correlation was detected between the UV values of the species by use category and density, frequency and dominance. This result suggest that it is not the environment, but rather other variables associated with individual criteria adopted by the informants that are influencing the use of species in the Itaúna Settlement Project. The correlation between the UV of plant families and density ( $r s=0.36, p=0.05)$, fre- quency ( $\mathrm{rs}=0.41, \mathrm{p}=0.03)$ and dominance $(\mathrm{r}=0.40, \mathrm{p}=0.03)$ were weak, indicating that use is not strongly correlated with the ecological apparency of the plant families in the area.

Among the four species with the highest UV values $(\geq 1)$, only Caryocar brasiliense also had a high IV (14.21), whereas Pterodon pubescens Hancornia speciosa and Hymenaea stigonocarpa had lower IVs (2.96-5.46). Among the eight species with an IV $\geq 10$, except by C. brasiliense and Sclerolobium paniculatum which had a UV $=0.93$, the other six species (Qualea parviflora, Davila elliptica, Kielmeyera coriacea, Ouratea hexasperma, Qualea grandiflora and Pouteria ramiflora) presented UV values ranging from 0.01 to 0.35 , lower than would be expected given their ecological apparency (Tab. 1).

Although we identified a relationship between the ecological apparency and use value of the woody plants of the protected area, the PCA showed that, for 14 species, use was inversely proportional to the values of density, frequency and dominance, as can be seen in Fig. 1. This biplot figure, with the scores and associated weights, shows that there are two principal components, representing $55.6 \%$ of total variance, the first explaining $42.6 \%$ and the second explaining $13.0 \%$. This representation demonstrates the ability of the first principal component to distinguish between species according to apparency, or phytosociological parameters (density, frequency and dominance) and that of the second principal component to distinguish between species by UV. On the left are located the species with higher density, frequency and dominance. Above the horizontal line are the species with the highest use value. As can be seen, four species clusters were formed. The first cluster showed a negative relationship between use value and apparency and consists of seven species (Pterodon pubescens, Hancornia speciosa, Hymenaea stigonocarpa, Annona crassiflora, Eugenia dysenterica, Stryphnodendron adstringens and Solanum lycocarpum) with medium and high UV values and medium to low density, frequency and dominance values. The second cluster is characterized by a positive relationship between apparency and use value, and has two species (Caryocar brasiliense and Sclerolobium paniculatum) with high UV, density, frequency and dominance values. The third cluster, with seven species of high apparency and low use value, comprises Byrsonima coccolobifolia, Salacia crassifolia, Qualea grandiflora, Pouteria ramiflora, Ouratea hexasperma, Kielmeyera coriacea and Dalbergia miscolobium. The fourth cluster is characterized by a positive relationship between species of low use value and apparency. It is the largest cluster, with 17 species, composed of Bowdichia virgilioides, Lafoensia pacari, Byrsonima crassifolia, Psidium laruotteanum, Palicourea rígida, Strychnos pseudoquina, Dimorphandra mollis, Psidium myrsinoides, Schefflera macrocarpa, Styrax ferrugineus, Vochysia rufa, Acosmium dasycarpum, Machaerium opacum, Tocoyena formosa, Himatanthus obovatus, Vochysia thyrsoidea and Agonandra brasiliense. Qualea parviflora and Davilla elliptica were removed from 


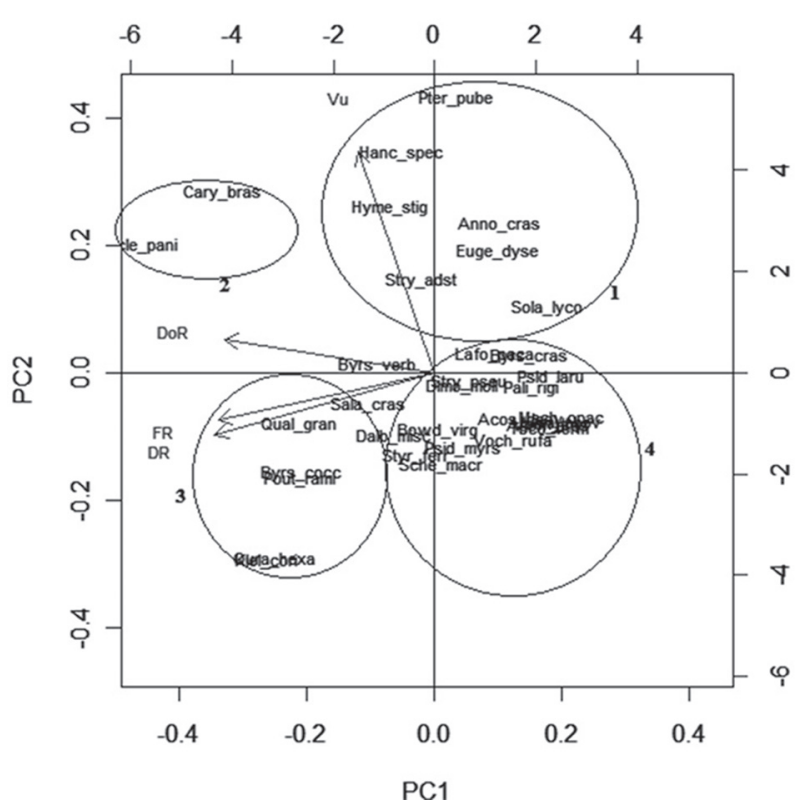

Figure 1. Principal component analysis of 34 useful species cited by residents of the Itáuna Settlement Project in the municipality of Planaltina, state of Goiás, Brazil. On the left are species with higher density, frequency and dominance. Above the horizontal line are the species with the highest UV values. VU - use value; DoR - relative dominance, FR - relative frequency, DR - relative density; Byrs_verb - Byrsonima verbascifolia; Group 1: Pter_Pube - Pterodon pubescens; Hanc_spec-Hancornia speciosa; Hyme_stig - Hymenaea stigonocarpa; Anno_cras - Annona crassiflora; Euge_dyse-Eugenia dysenterica; Stry_adst - Stryphnodendron adstringens; Sola_lyco - Solanum lycocarpum; Group 2: Cary_bras - Caryocar brasiliense; Scle_pani-Sclerolobium paniculatum; Group 3: Oura_hexa-Ouratea hexasperma; Kiel_cori - Kielmeyera coriacea; Pout_rami - Pouteria ramiflora; Byrs_cocc - B. coccolobifolia; Qual_gran - Qualea grandiflora; Sala_cras - Salacia crassifolia; Dalb_misc - Dalbergia miscolobium; Group 4: Bowd_virg - Bowdichia virgilioides; Lafo_paca - Lafoensia pacari; Byrs_crass - B. crassifolia; PC1 - first principal component; Psid_laru - Psidium laruotteanum; Pali_rigi - Palicourea rígida; Stry_pseu - Strychnos pseudoquina; Dimo_molli - Dimorphandra mollis; Psid_myrs - Psidium myrsinoides; Sche_macr - Schefflera macrocarpa; Styr_ferr - Styrax ferrugineus; Voch_rufa - Vochysia rufa; Acos_dasy-Acosmium dasycarpum; Mach_opac-Machaerium opacum; Toco_form - Tocoyena formosa; Hima_obov - Himatanthus obovatus; Voch_thyr - Vochysia thyrsoidea; Agon_bras - Agonandra brasiliense.

the PCA as outliers, with densities much higher than the other species. Byrsonima verbascifolia did not fit into any of the four clusters, as it presented moderate values for UV, density, frequency and dominance.

\section{Discussion}

\section{Use of resources}

Hancornia speciosa, Caryocar brasiliense and Sclerolobium paniculatum, which in this study presented the highest UV values, are of significant importance to the informants, similar to the importance found in the north of the state of Minas Gerais for timber and fruit species (Lima et al. 2012). Likewise, plants of the Fabaceae family were the most mentioned by a human population of the cerrado in the state of Mato Grosso (Moreira \& Guarim-Neto 2009) and by the informants of the Itaúna Settlement Project (in the present study). This similarity in results may be an early indication of a pattern of species and plant families most important to human populations within the cerrado biome.

Unlike the Amazon rain forest, where $40 \%$ of the uses of woody plants have been found to be timber-related (Galeano 2000), and the Caatinga biome, where timber products also seem to be one of the most important usage groups for the inhabitants of the region (Albuquerque et al. 2005; Lucena et al. 2007; Ramos et al. 2008; Ramos and Albuquerque 2012), the Cerrado does not show a high proportion of timber-related uses of woody plants, its inhabitants using such plants for their food potential. This may reflect the characteristics of cerrado trees, which, due to the tortuosity of their trunks and their small stature, are not always suitable for logging The cerrado trees can, however, be used as fuel (firewood and charcoal), which does not require the same characteristics, and on a smaller scale for construction projects, such as fences, corrals and huts.

Species with higher UV values were frequently cited for the use of their fruits, such as Pterodon pubescens, whose fruits are used as an antibiotic, and Hancornia speciosa and Caryocar brasiliense, whose fruits are used for food. Despite the availability of species with fruits be less throughout the year, compared to plants that offer medicinal and timber resources, this use was more widespread and had higher UVs.

As in the Itaúna Settlement Project, human populations studied in other areas have presented many uses concentrated in a few species and few uses for many species (Albuquerque \& Andrade 2002; Albuquerque et al. 2005; Ferraz et al. 2006; Galeano 2000; Luoga et al. 2000; Mutchnick \& Mccarthy 1997; Phillips et al. 1994; Stagegaar et al. 2002). Although the number of useful species with few citations of use tends to increase with the number of respondents, it is possible that many of the differences between the results reported in the literature are artifacts created by samples with different numbers of informants (Phillips et al. 1994).

Approximately half (49.3\%) of the species in our forest inventory were reported to be useful by the informants, more than a study observed in the Caatinga, where only $32.75 \%$ of the species were reported to be useful (Albuquerque et al. 2005). Research more focused on a particular category of use has the ability to enrich the list of useful plants (Monteiro et al. 2008) and, therefore, more detailed studies need to be done, possibly using other methods to obtain higher species richness of useful plants in the region. Consequently, the seasonal categories of use, such as food and medicinal categories, must be evaluated over the course of a year.

\section{Ecological apparency and UV}

As observed in the present study, the UV was found to correlate positively with phytosociological parameters (density, frequency and dominance) in a rural community in the Caatinga of northeastern brazil (Lucena 2009). However, 
in a transitional forest in Mexico, the correlation between the cultural importance of species, expressed by the UV, and their availability, expressed by the IV, was found to be weak (La Torre-Cuadros \& Islebe 2003). Studies conducted in regions with marked climatic seasonality have not found strong or significant correlations between these variables (Albuquerque et al. 2005; Ferraz et al. 2006; Lucena et al. 2007; Ramos et al. 2008). In the Itaúna Settlement Project, an area also characterized by striking climatic seasonality, we detected a weak trend for the most apparent species to be the most used. Therefore, it is not yet possible to assert that the ecological apparency hypothesis holds for the Cerrado biome. In addition, the lack of other studies testing this hypothesis in the Cerrado makes it impossible to compare results across studies.

In a study of the vegetation of a transitional forest in Mexico, La Torre-Cuadros \& Islebe (2003) found that not all species were used according to their availability. In the present study, the relationship between the use and abundance of plants was negative for 14 species used by the settlers, and seven of them (Pterodon pubescens, Hancornia speciosa, Hymenaea stigonocarpa, Annona crassifolia, Eugenia dysenterica, Stryphnodendron adstringens and Solanum lycocarpum) should preferentially be monitored, as they present high UV values and low density, dominance and frequency. It is not possible to assert that these species are suffering strong pressure due to use, given that no data were collected on the human management practices and environmental conditions over space and time that the harvesting occurs. The fact that these species are not ecologically apparent may be related to other factors, such as fire, which regularly affects part of the vegetation of the protected area of the settlement, or might even be because they are species occurring in low densities in. The high use value attributed to these seven species, despite their low abundance in the area, shows that they are widely known species and are of great importance for the region. Similarly, Lucena (2009) found many species of high use and low density in the areas studied in the Caatinga and did not attribute this result to the pressure of use, because species may have natural low densities and a high versatility of uses does not necessarily indicate anything regarding the actual collection and use of the resource.

Of the seven species with a high UV and low apparency in the protected area, six are used as timber, which is more destructive than other uses. The UV for these six species was more significant in the firewood category than in the construction category, which reduces the impact on the population, because the settlers often use dry fallen branches as firewood-no living organisms are cut. For the same reason, the collection of firewood was found not to be the major cause of deforestation in an area of Tanzania (Luoga et al. 2000).

Of the 19 species that showed a positive correlation with apparency, Caryocar brasiliense and Sclerolobium paniculatum are abundant in the protected area and heavily used by the informants for its valued fruit and wood for firewood and construction, respectively. The "charcoal tree" (S. paniculatum) is widely used as firewood and for civil construction in the rural areas (Oliveira et al. 2008). In an area of cerrado in the state of Maranhão, the "charcoal tree" showed the highest recruitment rate and annual diameter growth among 12 native species (Aquino et al. 2007), which may explain the high abundance of the species in the protected area. However, it also presented the second highest mortality rate (Aquino et al. 2007), which may also explain the high use of $S$. paniculatum for firewood in the Itaúna Settlement Project. C. brasiliense had low mortality, growth and recruitment in an area of cerrado in the north of Minas Gerais (Oliveira 2009), and because of its high density, the high UV based on fruit harvesting mainly does not seem to compromise this species persistence in the area.

Cultural factors determine the nature of plant use, and the most abundant species are not always the most important (Lucena et al. 2007), because the use varies among cultures (Phillips et al. 1994). In the caatinga, preference, rather than availability, acts as selection criteria for a given plant to be used as firewood (Ramos et al. 2008). This seems to occur in the cerrado as well, where species of widespread use, such as Hancornia speciosa, Eugenia dysenterica, and Pterodon pubescens, seem not to have a use necessarily related to the abundance of those species in the area but rather to the importance that the plants have for the local populations. However, species that have a high UV today, although of low current importance, may have been abundant in the past, so their large number of uses may reflect an ecological apparency from previous eras. The large quantity of migrants may also partially explain the fact that some of the more abundant and dominant species are not the most used, because people attribute uses to plants from their experiences in other environments, bringing with them this knowledge of other types of vegetation.

\section{Conclusion}

There are still no clear standards that would clarify the factors that influence the relationship between people and plant use. The few studies that have tested the ecological apparency hypothesis did not reach a consensus, although there was an indication that the hypothesis is valid for the Amazon biome and not for the caatinga.

There is a weak trend for phytosociological parameters to correlate positively with the use value, which may be due to the fact that usage information is related to the environment of origin of the settlers and not to the Itauna protected area. Accordingly, further studies are needed in order to test the ecological apparency hypothesis in different human settlements, seeking to further clarify aspects of the relationship between plant availability and local use of native species in the Cerrado biome. 
It is necessary to assess whether the high UV of Pterodon pubescens, Hancornia speciosa, Eugenia dysenterica, Hymenaea stigonocarpa, Stryphnodendron adstringens, Solanum lycocarpum and Annona crassiflora is having a negative effect on their population dynamics, and if they are being affected by external factors, such as fire, that may hinder their regeneration. More information on the ecology and cultural importance of these species is needed, given the high local demand for products derived from them.

The protected area studied here has a high non-commercial value for the settlers of the Itaúna Settlement Project, with the possibility to further increase plant utilization as the inhabitants increase their knowledge of the local vegetation. Ethnobotanical studies that consider a longer time frame are required in order to follow this process, looking for ways to express more precisely the use value of the resources of the cerrado for rural human populations.

\section{Acknowledgements}

The authors would like to thank the families of the Itaúna Settlement Project, for their support and participation in the project; Newton Rodrigues and André Coutinho, for their assistance in conducting the forest inventory; Joseane Padilha da Silva and Leticia Zenobia, for their help with the data analysis. This study received financial support from the Brazilian Instituto Sociedade, População e Natureza (ISPN, Institute for Society, Population and Nature) and the European Union, through the Universidades e Comunidades no Cerrado (UNICOM, Universities and Communities in the Cerrado) Program, as well as from the Brazilian Coordenação de Aperfeiçoamento de Pessoal de Nível Superior (CAPES, Office for the Advancement of Higher Education).

\section{References}

Albuquerque, U.P. \& Andrade, L.H.C. 2002. Uso de recursos vegetais da Caatinga: o caso do Agreste do estado de Pernamuco (Nordeste do Brasil). Interciencia 27: 336-346.

Albuquerque, U.P.; Andrade, L.H.C. \& Silva, A.C.O. 2005. Use of plant resources in a seasonal dry forest (Northeastern Brazil). Acta Botanica Brasilica 19: 27-38.

Aquino, F.G.; Walter, B.M.T. \& Ribeiro, J.F. 2007. Dinâmica de populações de espécies lenhosas de Cerrado, Balsas, Maranhão. Revista Árvore 31: 793-803.

Ayres, M.; Ayres Jr. M; Ayres, D.L. \& Santos, A.A.S. 2005. Bioestat 4.0 - Aplicações estatísticas nas áreas das ciências bio-médicas. Ong Mamiraua. Belém, PA.

Feeny, P. 1976. Plant Apparency and Chemical Defense. Pp. 1-40. In: Wallace, J.W. e Nansel, R.L. (Eds.). Biological Interactions Between Plants and Insects: Recent Advances in Phytochemistry. V. 10. New York, Plenum Press.

Ferraz, J.S.F.; Albuquerque, U.P. \& Meunier, I.M.J. 2006. Valor de uso e estrutura da vegetação lenhosa às margens do riacho do Navio, Floresta, PE, Brasil. Acta Botanica Brasilica 20: 125-134.

Forzza, R.C. et al. 2010. Síntese da diversidade brasileira. Pp. 21-42. In: Forzza, R.C. et al. (Eds.). Catálogo de plantas e fungos do Brasil. Rio de Janeiro, Andrea Jakobsson Estúdio: Instituto de Pesquisas Jardim Botânico do Rio de Janeiro.
Galeano, G. 2000. Forest Use at the Pacific Coast of Chocó, Colombia: A Quantitative Approach. Economic Botany 54: 358-376.

INCRA - Instituto Nacional de Colonização e reforma agrária. Superintendência regional do DF e Entorno - SR-28/DFE. 2008. Plano de desenvolvimento do assentamento - PDA. Projeto de assentamento Itáuna. Município de Planaltina de Goiás. Brasília.

La Torre-Cuadros, M. A. \& Islebe, G. A. 2003. Traditional ecological knowledge and use of vegetation in southeastern Mexico: a case study from Solferino, Quintana Roo. Biodiversity and Conservation 12: 2455-2476.

Lawrence, A.; Phillips, O.L.; Ismodes, A.R.; Lopez, M.; Rose, S.; Wood, D. \& Farfan, A. J. 2005. Local values for harvested forest plants in Madre de Dios, Peru: towards a more contextualized interpretation of quantitative ethnobotanical data. Biodiversity and Conservation 14: 45-79.

Lucena, R.F.P. 2009. Avaliando a eficiência de diferentes técnicas de coleta e análise de dados para a conservação da biodiversidade a partir do conhecimento local. Tese de doutorado em Botânica. Universidade Federal Rural de Pernambuco, Pernambuco.

Lucena, R.F.P.; Araújo, E.L. \& Albuquerque, U.P. 2007. Does the Local Availability of Woody Caatinga Plants (Northeastern Brazil) Explain Their Use Value? Economic Botany 61: 347-361.

Luoga, E.J.; Witkowski, E.T.E. \& Balkwill, K. 2000. Differential utilization and ethnobotany of trees in Kitulanghalo forest reserve and surrounding communal lands, eastern Tanzania. Economic Botany 54: 328-343.

Lima, I.L.P.; Scariot, A; Medeiros, M.B \& Sevilha, A.C. 2012. Diversidade e uso de plantas do Cerrado em comunidade de Geraizeiros no norte do Estado de Minas Gerais, Brasil. Acta Bot. Bras. 26: 675-684.

Medeiros, P.M.; Almeida, A.L.S.; Lucena, R.F.P. \& Albuquerque, U.P. 2008. Uso de estímulos visuais na pesquisa etnobotânica Pp. 109-126. In: Albuquerque, U.P., Lucena, R.F.P., Cunha, L.V.F.C. (orgs). Métodos e técnicas na pesquisa etnobotânica.

Myers, N.; Mittermeier, R.A.; Mittermeier, C.G.; Fonseca, G.A.B. \& Kent, J. 2000. Biodiversity hotspots for conservation priorities. Nature 403:853-858.

MMA (Ministério do Meio Ambiente). 2010. http://www.mma.gov.br/ portalbio (Acesso em 31/08/2010).

Monteiro, J.M.; Lucena, R.F.P.; Alencar, N.L.; Nascimento, V.T. \& Araújo, T.A.S. 2008. When intention matters: Comparing three ethnobotanical data collection strategies. Pp. 113-124. In: Albuquerque, U.P.; Ramos, M.A. (Eds.). Current Topics in Ethnobotany.

Moreira, D.L. \& Guarim-Neto, G. 2009. Usos múltiplos de plantas do Cerrado: um estudo etnobotânico na comunidade sítio Pindura, Rosário Oeste, Mato grosso, Brasil. Polibotanica. 27: 159-190.

Mutchnick, P.A. \& Mccarthy, B.C. 1997. An ethnobotanical analysis of the tree species common to the subtropical moist forests of the petén, Guatemala. Economic Botany 51: 158-183.

Oksanen, J.; Kindt, R.; Legendre, P.; O’hara, B.; Simpson, G.L. \& Henry, M.H. Stevens and Helene Wagner (2008). Vegan: Community Ecology Package. R package version 1.13-1. http://vegan.r-forge.r-project.org/

Oliveira, I.R.M.; Vale, A.T.; Melo, J.T.; Costa, A. F. \& Gonçalez, J.C. 2008. Biomassa e características da madeira de Sclerolobium paniculatum cultivado em diferentes níveis de adubação. Cerne 14: 351-357.

Oliveira, W.L. 2009. Ecologia Populacional e extrativismo de frutos de Caryocar brasiliense Camb. no Cerrado no norte de Minas Gerais. Dissertação de mestrado. Universidade de Brasília, Brasília.

Phillips, O. \& Gentry, A.H. 1993a. The useful plants of Tambopata, Peru: I. Statistical hypotheses tests with a new quantitative technique. Economic Botany 47: 15-32.

Phillips, O. \& Gentry, A.H. 1993b. The useful plants of Tambopata, Peru: II. Additional hypothesis testing in quantitative ethnobotany. Economic Botany 47: 33-43.

Phillips, O.; Gentry, A.H.; Reynel, C.; Wilkin, P. \& Galvez-Durand, C. 1994. Quantitative ethnobotany and Amazonian conservation. Conservation Biology 8: 225-248.

R Development Core Team 2008. R: A language and environment for statistical computing. R Foundation for Statistical Computing, Vienna, Austria. ISBN 3-900051-07-0, URL http://www.R-project.org. 
Ramos, M.A.; Medeiros, P.M.; Almeida, A.L.S.; Feliciano, A.L.P. \& Albuquerque, U.P. 2008. Use and knowledge of fuelwood in an area of Caatinga vegetation in NE Brazil. Biomass and bioenergy 32: 510-517.

Ramos, M.A. \& Albuquerque, U.P. 2012. The domestic use of firewood in rural communities of the Caatinga: How seasonality interferes with patterns of firewood collection. Biomass and Bioenergy 39:147-158.

Rossato, S. C., Leitao-Filho, H. F. \& Begossi, A. 1999. Ethnobotany of Caiçaras of the Atlantic Forest coast (Brazil). Economic Botany 53: 387-395. Scariot, A. 2010. Panorama da Biodiversidade Brasileira Pp. 111-130. In: Ganem, R.S. (Org.). Conservação da Biodiversidade: Legislação e Políticas Públicas. Brasília, Camâra dos Deputados.

Stagegaard, J.; Sørensen, M. \& Kvist, L.P. 2002. Estimations of the importance of plant resources extracted by inhabitants of the Peruvian Amazon flood plains. Urban e Fischer Verlag 5: 103-122. 